\title{
Monokine Secretion in Aging and Protein Malnutrition
}

\author{
Suzanne F. Bradley, Asda Vibhagool, Steven L. Kunkel, and Carol A. Kauffman \\ Division of Infectious Diseases, Department of Internal Medicine (S.F.B., A.V., C.A.K.), and Department of \\ Pathology (S.L.K.), University of Michigan Medical School, and Veterans Administration Medical Center, \\ Ann Arbor, Michigan
}

\begin{abstract}
Aged and protein-malnourished hosts have diminished febrile responses and increased morbidity and mortality from infection that could be due to deficiencies in the production of certain monokines. In this study, the ability of pertitoneal macrophages from aged and protein-malnourished rats to produce IL-1 and TNF was explored. Aged rats fed a standard diet produced leas IL-1 and TNF, as moasured by the thymocyte prolfieration and L929 cytotoxicity assays, than young and middlo-aged rats. Monokine production was not diminished by protein malnutrition in any age group. No synergiatic decline in IL-1 or TNF production was seen with increasing age in malnourished rats. Diminished IL-1 and TNF production may partially explain the severity of infection seen in the elderly patient, but not the malnourished host. The role of other cytokines such as IL-6 and cytokine inhibltors in aging and malnutrition should be explored.
\end{abstract}

Key words: interloukin-1, tumor necrosis factor, cytokines

\section{INTRODUCTION}

In debilitated hosts, especially the aged and malnourished, the course of infection can be particularly severe, frequently ending in death $[3,33]$. Why the aged and malnourished are more easily infected or fail to clear a pathogen may relate to environmental factors, such as those found in nursing homes and hospitals that harbor antibiotic-resistant bacteria [17]; breakdown of anatomic barriers, such as might occur with decubitus ulcers; underlying illnesses; or defects in immunity [15]. Both aging and malnutrition are accompanied by significant changes in the immune response $[4,15,27]$. Defects in nonspecific inflammatory responses, such as fever, also have been described in both elderly and malnourished humans $[9,36]$. In several studies, an inability to mount a febrile response has been associated with a higher mortality from infection $[14,33]$. In this study, we evaluated whether the production or secretion of monokines that serve as febrile mediators, interleukin-1 (IL-1) and tumor necrosis factor (TNF), are diminished in an animal model of aging and moderate protein malnutrition [8].

\section{MATERIALS AND METHODS}

\section{Animals}

Specific pathogen-free young (2-3 months), middleaged (12-13 months), and aged (22-23 months) Fischer 344 male rats (Harlan Sprague Dawley, Inc., Indianapolis, IN) were individually housed in wire mesh cages and maintained on a $12 \mathrm{hr}$ light-dark photoperiod at an ambient temperature of $26 \pm 1^{\circ} \mathrm{C}$.

\section{Diets}

The control diet consisted of standard rat chow (5001, Ralston Purina, Inc., St. Louis, MO), containing 23\% protein. The low protein diet consisted of an isocaloric 8\% casein chow (ICN Biochemicals, Inc., Cleveland, $\mathrm{OH}$, which causes moderate, but not severe, protein malnutrition. The major components and kilocalories contained in each diet have been described previously [8]. Young rats were fed the experimental diets for 4 weeks and middle-aged and aged rats for 6 weeks to ensure moderate protein malnutrition [8] before harvesting their peritoneal macrophages.

\section{Experimental Design}

In each age group 20 rats were fed the low protein diet and 20 rats were fed the standard chow. After consumption of the diets for the times indicated above, peritoneal macrophages were harvested to assess the ability of rats of different ages and on different diets to secrete monokines, as measured by thymocyte proliferation and fibroblast cytotoxicity. Thus, when studied, animals were 3-4 months old (young), 13-14 months old (middleaged), and 23-24 months old (aged).

Received September 13, 1988; accepted January 12, 1989.

Reprint requests: Suzanne F. Bradley, Veterans Administration Medical Center, 2215 Fuller Road, Ann Arbor, MI 48105. 


\section{Assay for Protein Malnutrition}

After peritoneal macrophages were harvested, the liver was removed and stored at $-70^{\circ} \mathrm{C}$; L-alanine aminotransferase (ALT) activity and total protein content were determined as previously described $[18,26]$.

\section{Monokine Production}

Three days before harvest of peritoneal macrophages, rats were injected intraperitoneally with $30 \mathrm{ml}$ of shellfish glycogen (Sigma, Inc., St. Louis, MO) in 0.9\% $\mathrm{NaCl}(0.2 \mathrm{~g} / \mathrm{dl})$. Three days later, macrophages were washed from the peritoneal cavity with Hanks' balanced salt solution and heparin ( 1 unit/ml) as previously described [7]. Macrophages at a concentration of $2.5 \times$ $10^{6}$ cells $/ \mathrm{ml}$ were mixed with Staphylococcus epidermidis to stimulate monokine secretion as described before [23].

\section{Thymocyte Proliferation Assay for IL-1 Activity}

Thymocytes from 8-week-old C3H/HeJ mice (Jackson Laboratories, Woods Hole, MA) were cultured at $2.5 \times$ $10^{6}$ cells $/ \mathrm{ml}$ in RPMI-1640 with $10 \%$ fetal calf serum, glutamine, penicillin, and streptomycin in a $0.2 \mathrm{ml}$ volume in flat-bottom microtiter plates [28]. Phytohemagglutinin (PHA) $(2 \mu \mathrm{g} /$ well) (Burrough-Wellcome, Inc., Research Triangle Park, NC) was added to each well, along with $10 \mu \mathrm{l}$ of varying dilutions (undiluted to $1: 100$ ) of macrophage supernatants in RPMI-1640. After 3 days of incubation at $37^{\circ} \mathrm{C}$ in $5 \% \mathrm{CO}_{2}, 1 \mu \mathrm{C}{ }^{3} \mathrm{H}$ thymidine was added to each well. The cells were harvested after $4 \mathrm{hr}$ with a cell harvester, and ${ }^{3} \mathrm{H}$ activity was assayed in a beta counter. IL-1 activity was calculated with a standard curve derived by plotting proliferation of thymocytes expressed as disintegrations per minute or DPM against units per milliliter of human rIL-1 alpha (Genzyme Inc., Boston; MA).

\section{Inactivation of Interleukin-1 Activity}

Macrophage supernatants were heated or mixed with various dilutions of anti-IL-1 or anti-TNF to help determine which monokine was responsible for the proliferative effects. Human rlL-1 alpha $(100 \mathrm{U} / \mathrm{ml})$ (Genzyme, Inc.), human rTNF alpha $(500 \mathrm{U} / \mathrm{ml})$ (Endogen Inc., Boston, MA), and control rat macrophage supernatants were mixed 1:1 with various dilutions in RPMI-1640 (1:10-1:2000) of antimurine IL-1 (gift of Dr. Stephen Chensue), antimurine TNF alpha (Genzyme, Inc.), or RPMI-1640 for $1 \mathrm{hr}$ before adding $10 \mu \mathrm{l}$ amounts to wells containing thymocytes. In another experiment, rIL-1 and control rat macrophage supernatants were heated at $70^{\circ} \mathrm{C}$ for $30 \mathrm{~min}$, as previously described [7], before adding $10 \mu l$ to wells containing thymocytes and testing for proliferation. In both experiments, samples
TABLE 1. Effect of Low-Protein Diet on Liver L-Alanine Aminotransferase Activity in Three Age Groups

\begin{tabular}{lccc}
\hline & \multicolumn{3}{c}{$\begin{array}{c}\text { L-alanine aminotransferase activity } \\
\text { (units/mg protein) }\end{array}$} \\
\cline { 2 - 4 } Age group (months) & Control diet & Low-protein diet & $P$ value \\
\hline $2-3$ & $0.38 \pm 0.01$ & $0.20 \pm 0.01$ & $<.0005$ \\
$12-13$ & $0.37 \pm 0.02$ & $0.22 \pm 0.01$ & $<.0005$ \\
$22-23$ & $0.24 \pm 0.01$ & $0.14 \pm 0.01$ & $<.0005$ \\
\hline
\end{tabular}

aData are expressed as mean \pm SEM.

bStatistical differences shown are for control vs. malnourished rats in each age group. In addition, elderly rats in both control and malnourished groups had significantly less ALT activity than the younger rats $(P<.0005)$.

were tested in quadruplicate. Data were expressed as stimulation index, DPM PHA + sample/DPM PHA.

\section{L929 Cytotoxicity Assay for TNF Activity}

L929 cells $\left(5 \times 10^{4}\right.$ cells $\left./ 0.1 \mathrm{ml}\right)$ in RPMI- 1640 with glutamine, penicillin, and streptomycin were placed into flat-bottom microtiter plates for $18 \mathrm{hr}$ at $37^{\circ} \mathrm{C}$ in $5 \% \mathrm{CO}_{2}$ in the presence of $1 \mu \mathrm{g} / \mathrm{ml}$ actinomycin $D$ and varying dilutions of macrophage supernatants in RPMI-1640 (undiluted to 1:100). After incubation, the plates were washed and stained with crystal violet; the amount of lysis was determined with a micro-ELISA reader as previously described [1].

\section{Data Analysis}

Data from the two differnt groups of rats (protein malnourished and control diets) were compared by Student's $t$ test. Data from the three different age groups were compared with Bonferroni's $t$ test for comparison of more than two groups.

\section{RESULTS}

The rats in each age group receiving the $8 \%$ casein diet were significantly protein deprived, as shown by their lower liver ALT activities (Table 1). The liver ALT content in elderly rats was significantly lower than that in both middle-aged and young rats for those on both the control diet and the $8 \%$ casein diet.

Protein malnutrition did not appear to decrease TNF secretion when protein-malnourished rats were compared with control rats in each of the three age groups (Fig. 1). However, there was a fall in TNF activity with increasing age. Both middle-aged and elderly rats showed significantly less TNF activity than the younger rats. This was true for the control diet rats $(P<.0005$ for both young vs. middle aged rats and for young vs. elderly rats) and the low-protein-diet rats $(P<.0005$ for young vs. elderly rats and $P=.015$ for young vs. middle-aged rats) (Bonferroni's $t$ test).

According to a thymocyte proliferation assay for IL-1 activity, protein malnutrition did not cause decreased 


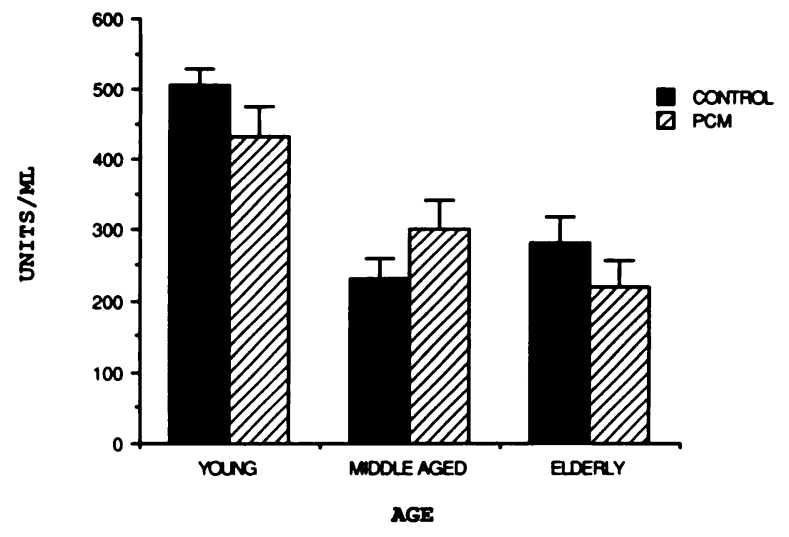

Fig. 1. Tumor necrosis factor (TNF) activity from peritoneal macrophages of control and protein-malnourished (PCM) rats in three different age groups, shown as mean units per milliliter with standard error of the mean (SEM) indicated. In each age group, differences between protein-malnourished and control rats were not statistically significant. In the control diet groups, the young rats differed significantly from the middle-aged $(P<$ $.0005)$ and the elderly rats $(P<.0005)$ in TNF production. In the protein-deficient-diet groups, also, the young rats differed significantly from the elderly $(P<.0005)$ and the middle-aged rats $(P=.015)$ in TNF production.

secretion of IL-1 by peritoneal macrophages (Fig. 2). In each age group, differences in IL-1 production between protein-malnourished and control rats were not significant. However, aging appeared to decrease the secretion of IL-1; elderly rats fed the control diet had less IL-1 activity in macrophage supernatants than both middleaged rats $(P<.01)$ and young rats $(P<.01)$ on the control diet (Bonferroni's $t$ test). In rats fed the proteindeficient diet, there were no significant differences among the three age groups.

The proliferative activity of rat macrophage supernatants was inhibited by antimurine $\mathrm{IL}-1$, but not by anti-murine TNF (Table 2). The addition of human TNF (2.5 U/well) did not cause thymocyte proliferation. Heat treatment of both rIL-1 and the rat macrophage supernatants inhibited their ability to stimulate thymocyte proliferation.

\section{DISCUSSION}

The association of increasing age with a diminished febrile response during infection has been a common medical teaching for centuries [35]. Justification for this observation is derived primarily from clinical studies of acute, serious illness in which the aged were less likely to develop a fever and were more likely to die from infection than other age groups $[14,16,33]$. In other studies of infection in the elderly, diagnostic localizing signs and other parameters of inflammation were often

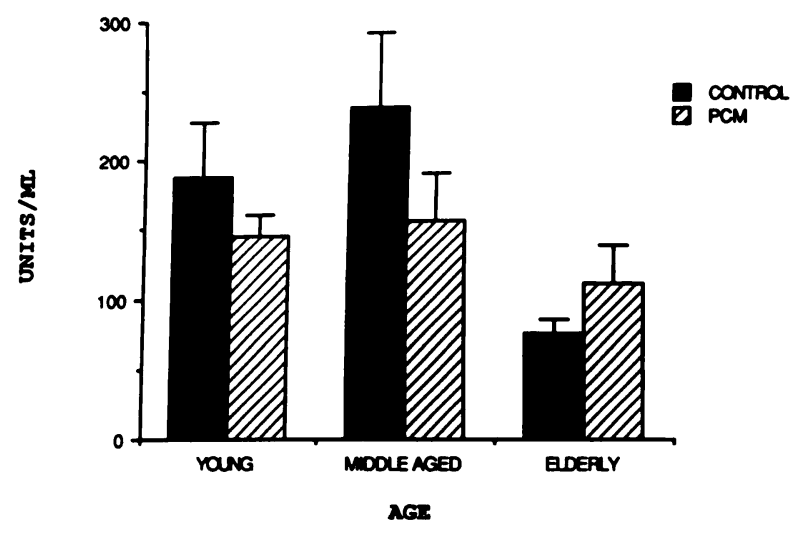

Fig. 2. Interloukin-1 (IL-1) activity from peritoneal macrophages of control and protein-mainourished (PCM) rats in three different age groups, shown as mean units per milliliter with SEM indicated. In each age group, differences between proteinmalnourished and control rats were not statistically significant. In the control diet groups, elderly rats showed significantly less IL-1 activity than middle-aged $(P<.01)$ or young rats $(P<.01)$.

TABLE 2. Neutrallzation of IL-1-Initiated Thymocyte Proliferation by Antibodies to Monokines and Heating"

\begin{tabular}{lcccc}
\hline & \multicolumn{4}{c}{ Mean stimulation index } \\
\cline { 2 - 5 } Pretreatment & $\begin{array}{c}\text { Human } \\
\text { rIL-1 }\end{array}$ & $\begin{array}{c}\text { Rat 1 } \\
\text { supernatant }\end{array}$ & $\begin{array}{c}\text { Rat 2 } \\
\text { supernatant }\end{array}$ & $\begin{array}{c}\text { Human } \\
\text { rTNF }\end{array}$ \\
\hline None & 24.5 & 12.7 & 8.3 & 1.7 \\
Antimurine & 12.9 & 2.1 & 2.3 & - \\
$\quad \begin{array}{l}\text { IL-1 } \\
\text { Antimurine }\end{array}$ & - & 23.6 & 17.5 & 3.9 \\
$\quad$ TNF & & & & \\
$70^{\circ} \mathrm{C}, 30 \mathrm{~min}$ & 1.8 & 2.4 & 1.6 & - \\
\hline
\end{tabular}

aAll assays run in quadruplicate in the presence of $2 \mu \mathrm{g}$ PHA/well.

diminished or absent $[2,34]$. In a model of sublethal Salmonella infection, aged rats had significantly less fever than their middle-aged counterparts [6]. The paucity of inflammatory signs in the aged might suggest a defect in such mediators as TNF and IL-1.

Our study corroborates the results found by other investigators who noted that supernatants from aged murine peritoneal macrophages had less IL-1 activity than supernatants from other age groups, as measured by the thymoctye proliferation assay $[10,21]$. However, using Lewis rats, Rosenberg et al. [32] found no decline in IL-1 production with increasing age. The differences between Rosenberg's results and ours may relate to different rat strains, different assays for IL-1, and perhaps other methodologic differences.

The ability of aged hosts to produce TNF has not been assessed previously. In this study, aged rat macrophages produced less TNF than macrophages from younger rats, as measured by the L929 cytotoxicity assay.

In contrast, when the rat febrile-response assay was 
used to measure endogenous pyrogen production from either human monocytes or rat macrophages, no agerelated decline in production of pyrogens was seen $[22,23]$. Whereas the thymocyte proliferation assay measures predominantly IL-1 activity and the L929 assay measures primarily TNF, especially when run with antibody controls to help ensure specificity, the febrileresponse assay is influenced by the presence of $\mathrm{IL}-1$, TNF, IL-6, and perhaps other mediators as well [13]. This could explain the dichotomy between the results obtained with the two different assays.

Why aged macrophages produced less IL-1 and TNF is unclear. Both cytokines cause a wide range of metabolic effects, some of which may be beneficial. Lower levels of monokines in the aged might explain, in part, their increased morbidity and mortality from infection. In animal studies of bacterial infection, supplementation with IL-1 or TNF provided protection, presumably by augmenting nonspecific host defense mechanisms [5, $11,12,30,31]$.

Other factors, in addition to aging, may influence the incidence and outcome of infection in elderly populations. Protein malnutrition occurs commonly in elderly hospitalized patients [29]. Protein deprived hosts, like the elderly, are more susceptible to infection and are less likely to survive than hosts that have an adequate protein intake [3]. Similarly, protein-malnourished hosts have also been found to have diminished febrile responses, usually in the face of sepsis or overwhelming infection $[9,19]$.

In previous studies, when supernatants derived from either macrophages of protein-deprived animals or monocytes of protein-malnourished humans were assayed by injection into normal animals, febrile responses and acute-phase reactants were diminished, when compared with responses after injection of monocyte or macrophage supernatants from control subjects $[7,19,20,24,25]$. These studies suggested that protein-malnourished hosts had a deficiency in mediators of fever and acute-phase reactants, such as IL-1 and TNF. However, our current experiments using thymocyte stimulation and cytotoxicity assays for IL-1 and TNF, respectively, did not show any diminished activity related to protein malnutrition.

Thus, endogenous pyrogen assays showed normal production of pyrogenic monokines by macrophages of aged animals, but diminished production by cells from protein-malnourished animals. On the other hand, in vitro assays for IL-1 and TNF showed the opposite results: aging appeared to decrease both IL-1 and TNF activity, whereas protein malnutrition did not diminish activity of either monokine. The decrease in fever and other nonspecific host defense mechanisms in the malnourished could be due to deficiencies in other cytokines, such as IL-6, which were not measured in this study. Protein-malnourished hosts could also produce inhibitors to IL-1 or TNF, which might influence fever production in vivo, but may not be evident in the in vitro assays performed in this study.

No synergistic effect of age and malnutrition on IL-1 and TNF production was seen in this study. Similarly, no synergistic decrease in the febrile response was seen with age and malnutrition in rats injected with pyrogens in a previous study [8]. Further studies need to be done to delineate the underlying defects present in the malnourished host. Other factors may contribute to the development of infection in certain elderly populations.

\section{ACKNOWLEDGMENTS}

This work was supported by the Veterans Administration Research Service and by Public Health Service New Investigator Research Award DK 37993 from the National Institute of Diabetes and Digestive and Kidney Diseases.

\section{REFERENCES}

1. Bachwich, P.R., Lynch, J.P., Larrick, J., Spengler, M., and Kunkel, S.L. Tumor necrosis factor production by human sarcoid alveolar macrophages. Am. J. Pathol. 125,421, 1986.

2. Beaumont, D.M., and Davis, M. Clinical presentation of pyogenic liver abscess in the elderly. Age Ageing 14,339, 1985.

3. Bienia, R., Ratcliff, S., Barbour, G.L., and Kummer, M. Malnutrition in the hospitalized geriatric patient. J. Am. Geriatr. Soc. 30,433, 1982.

4. Bistrian, B.R., Blackburn, G.L., Scrimshaw, N.S., and Flatt, J.P. Cellular immunity in semistarved states in hospitalized adults. Am. J. Clin. Nutr. 28,1148, 1975.

5. Blanchard, D.K., Djen, J.Y., Klein, T.W., Friedman, H., and Stewart, W.E. Protective effects of tumor necrosis factor in experimental Legionella pneumophila infections of mice via activation of PMN function. J. Leukocyte Biol. 43,429, 1988.

6. Bradley, S.F., and Kauffman, C.A. Aging and the response to Salmonella infection. (Manuscript submitted.)

7. Bradley, S.F., and Kauffman, C.A. Protein malnutrition and the febrile response in the Fischer rat. J. Leukocyte Biol. 43,36, 1988.

8. Bradley, S.F., Kluger, M.J., and Kauffman, C.A. Age and protein malnutrition: Effects on the febrile response. Gerontology 33,99, 1987.

9. Brenton, D.P., Brown, R.E., and Wharton, B.A. Hypothermia in kwashiorkor. Lancet 1,410, 1967.

10. Bruley-Rosset, M., and Vergnon, I. Interleukin-1 synthesis and activity in aged mice. Mech. Ageing Dev. 24,247, 1984.

11. Czuprynski, C.J., and Brown, J.F. Recombinant murine interleukin-la enhancement of nonspecific antibacterial resistance. Infect. Immun. 55,2061, 1987.

12. Czuprynski, C.J., Brown, J.F., Young, K.M., Cooley, A.J., and Kurtz, R.S. Effects of murine recombinant interleukin-la on the host response to bacterial infection. J. Immunol. 140,962, 1988.

13. Dinarello, C.A., Cannon, J.G., Wolff, S.M., Bernheim, H., Beutler, B., Cerami, A., Figari, I.S., Palladino, M.A., and O'Connor, J.V. Tumor necrosis factor (cachectin) is an endoge- 
nous pyrogen and induces production of interleukin-1. J. Exp. Med. 163,1433, 1986.

14. Finkelstein, M.S., Petkun, W.M., Freedman, M.L., and Antopol, S.C. Pneumococcal bacteremia in adults. J. Am. Geriatr. Soc. $31,19,1983$.

15. Gardner, I.D. The effect of aging on suceptibility to infection. Rev. Infect. Dis. 2,801, 1980.

16. Gleckman, R., and Hibert, D. Afebrile bacteremia: A phenomenon in geriatric patients. JAMA 248,1478, 1982.

17. Gross, P.A., Neu, H.C., Aswapokee. P., van Antwerpen, C., and Aswapokee, N. Deaths from nosocomial infections: Experience in a university and a community hospital. Am. J. Med. 68,219, 1980.

18. Heard, C.R.C., Frangi, S.M., Wright, P.M., and McCartney, P.R. Biochemical characteristics of different forms of proteinenergy malnutrition: An experimental model using young rats. Br. J. Nutr. 37,1, 1977.

19. Hoffman-Goetz, L., and Kluger, M.J. Protein deprivation: Its effects on fever and plasma iron during bacterial infection in rabbits. J. Physiol. (Lond.) 295,419, 1979.

20. Hoffman-Goetz, L., McFarlane, D., Bistrian, B.R., and Blackburn, G.L. Febrile and plasma iron responses of rabbits injected with endogenous pyrogen from malnourished patients. Am. J. Clin. Nutr. 34,1109, 1981.

21. Inamizu, T., Chang, M.P., and Makinodan, T. Influence of age on the production and regulation of interleukin-1 in mice. Immunology 55,447, 1985.

22. Jones, P.G., Kauffman, C.A., Bergman, A.G., Hayes, C.M. Kluger, M.J., and Cannon, J.G. Fever in the elderly: Production of leukocytic pyrogen by monocytes from elderly persons. Gerontology 30,182, 1984.

23. Kauffman, C.A. Endogenous pyrogen/interleukin-1 production in aged rats. Exp. Gerontol. 21,75, 1984.

24. Kauffman, C.A., Jones, P.G., and Kluger, M.J. Fever and malnutrition: Endogenous pyrogen/interleukin-1 in malnourished patients. Am. J. Clin. Nutr. 44,449, 1986.
25. Keenan, R.A., Moldawer, L.L., Yang, R.D., Kawamura, I., Blackburn, G.L., and Bistrian, B.R. An altered response by peripheral leukocytes to synthesize or release leukocyte endogenous mediator in critically ill protein-malnourished patients. J. Lab. Clin. Med. 100,844, 1982.

26. Lowry, O.H., Rosebrough, N.J., Farr, A.L., and Randall, R.J. Protein measurement with the Folin phenol reagent. J. Biol. Chem. 193,265, 1951.

27. Mackinodan, T., and Kay, M.M.B. Age influence on the immune system. Adv. Immunol. 29,287, 1980.

28. Mizel, S.D., Oppenheim, J.J., and Rosenstreich, D.L. Characterization of lymphocyte-activating factor (LAF) produced by the macrophage cell line P388D. J. Immunol. 120,1497, 1978.

29. Morley, J.E. Nutritional status of the elderly. Am. J. Med. $81,679,1986$.

30. Ozaki, Y., Ohashi, T., Minami, A., and Nakamura, S. Enhanced resistance of mice to bacterial infection induced by recombinant human interleukin-1a. Infect. Immun. 55,1436, 1987.

31. Parant, M., Parant, F., Vinit, M., and Chedid, L. Action protectrice du tumor necrosis factor (TNF) obtenu par recombinaison genetique contre l'infection experimentale bacterienne ou fongique. C.R. Acad. Sci. (III) 304,1, 1987.

32. Rosenberg, J.S., Gilman, S.C., and Feldman, J.D. Effects of aging on cell cooperation and lymphocyte responsiveness to cytokines. J. Immunol. 130,1754, 1983.

33. Weinstein, M.P., Murphy, J.R., Reller, L.B., and Lichtenstein, K.A., The clinical significance of positive blood cultures: A comprehensive analysis of $\mathbf{5 0 0}$ episodes of bacteremia and fungemia in adults. Rev. Infect. Dis. 5,54, 1983.

34. Williams, J.S., and Hale, H.W. Acute appendicitis in the elderly: Review of 83 cases. Ann. Surg. 162,208, 1965.

35. Wunderlich, A., and Seguin, E. Medical Thermometry and Human Temperature. New York: William Wood \& Co., p. 62, 1871.

36. Yoshikawa, T.T. Geriatric infectious diseases: An emerging problem. J. Am. Geriatr. Soc. 31,34, 1983. 